\title{
Influence of Gamma Irradiation on Seedless Citrus Production: Pollen Germination and Fruit Quality
}

\author{
Almudena Bermejo*, José Pardo, Antonio Cano \\ Citrus and Vegetable Production Department, Institute Valenciano of Agricultural Research (IVIA), Moncada-Náquera, Valencia, \\ Spain. \\ Email: bermejo_alm@gva.es
}

Received February $3^{\text {rd }}, 2011$; Revised March $3^{\text {rd }}, 2011$; Accepted March 31 ${ }^{\text {st }}, 2011$.

\begin{abstract}
Seedlessness is a desirable characteristic in citrus fruits sold for fresh consumption. Gamma irradiation is widely used to obtain seedless citrus fruits. Here, different clones of the self-incompatible parthenocarpic "Moncada" mandarin, obtained by gamma irradiation, were studied to assess seedlessness, pollen germination, fruit characteristics and quality attributes. Findings indicate that irradiation altered aspects oth er than seedlessness, such as pollen germination, and some of the clones presented different weight, size, acidity and maturity index. Fruit quality and nutritional biocomponents were affected differently; some clones presented no changes compared to the control "Moncada" mandarin, while other clones showed significant differences. In general, all clones examined presented low seed numbers and reduced pollen viability. Some of these clones, which ripen late in the season and whose fruit quality is maintained or improved, are in the process of registration.
\end{abstract}

Keywords: Citrus Clones, Nutritional Bio-Components, Fruit Quality, Gamma Irradiation, Seedlessness, Pollen Germination

\section{Introduction}

Citrus is one of the most economically important fruit crops in the world. With the development of the processing industry and the demand for higher quality fruit, the production of fruits with few or no seeds has steadily increased [1]. Seedlessness is an important economic trait relating to fruit quality. There are many desirable characteristics of seedless fruit, which include high quality and taste, which are greatly valued by both consumers and the processing industry. The presence of a large number of seeds in citrus fruits greatly hinders consumer acceptability, even if it has good organoleptic properties. Therefore, the development of seedless fruit cultivars has become a major goal for fruit breeders around the world and different approaches have been adopted by numerous researchers. Great achievements have been made over the past few decades in seedless breeding techniques with fruits such as citrus, grape (Vitis vinifera L.), litchi (Litchi chinensis Sonn.), loquat (Eriobotrya japonica Lindl. cv. Jiefangzhong), mango (Mangifera indica Linn.) and wampee (Clausena lansium Lour.) [1-3]. Thus, among citrus cultivars, mutation breeding has been used to improve sweet orange (Citrus sinensis (L.) Osb.), grapefruit (C. paradisi Macf.) and mandarin (C. reticulata Blanco) $[4,5]$.

Seedlessness in citrus mandarin cultivars can be induced by many factors, including female or male sterility, defective ovules and embryo-sacabortion, pollen selfincompatibility, polyploidy, abnormal climate and application of plant-growth regulators, such as gibberellins. Yamamoto et al. [3] investigated the relationship between female and male sterility, and self-incompatibility, with seed content in citrus fruits, showing that self-incompatibility as well as male sterility effectively reduces seediness [6,7]. Many seedless citrus cultivars, especially seedless mandarin cultivars, originate from the bud mutation of seedy cultivars [8]. Research into this matter is essential to understand the relationship between bud variation and the mechanism of seedlessness [1].

Mutation breeding has been used not only to obtain seedless cultivars, but also to improve other characteristics of citrus, as in "Sunki" spine-free mandarin [9], the fleshy red colour of "Star Ruby" grapefruit [10] and "Mal Secco" tolerance in lemon (C. limon (L.) Burm f. [11]. Another question to consider is the effect of irradiation 
on the quality of different mutants. Qualities of the control cultivar have to be kept or improved in the new varieties, along with the seedless quality. Fruit weight, size, acidity, maturity index, harvest time, chemical and nutritional composition are important quality traits for fresh citrus consumption and acceptance by the citrus industry.

Citrus fruits have received much attention due to their nutritional and antioxidant properties and currently the prevention of health problems through nutrition is being promoted intensively [12-15], due mainly to the contribution of antioxidant compounds, including vitamin $\mathrm{C}$, phenolic compounds and carotenoids. Organic acids, sugars and phenolic compounds are among the major compounds of citrus fruit.

Previously, we have studied the chemical variability of bioactive compounds in citrus pulp and juice and its relationship with genetic and climatic factors. More recently, we have evaluated the rind content of bioactive constituents (flavonoids, carotenoids, vitamin-C, essential oils and mineral composition) in several mandarin and orange cultivars $[16,17]$. In citrus, the major part of the total antioxidant activity is due to hydrophilic compounds [18], and some authors have shown the important role played by hesperidin in the antioxidant capacity of orange juices [14].

Gamma irradiation is a common technique used to obtain seedless citrus fruits. Herein, we report a study of thirteen new seedless "Moncada" mandarin clones of the self-incompatible parthenocarpic "Moncada" mandarin obtained by gamma irradiation. The original hybrid "Moncada" mandarin control "Oroval" $\times$ "Kara" (C. clementina Hort. ex Tan. $\times(C$. unshiu Marc. $\times$ C. nobilis Lour.)) was previously obtained in 1980 through a breeding program held at Instituto Valenciano de Investigaciones Agrarias (IVIA) by R. Bono et al. This cultivar demonstrates excellent agronomical behaviour, fruit size, internal quality, good rind colour, is easy to peel, which ripen period is January an February, and almost completely seedless if grown in isolation [19]. However, this mandarin cultivar can be very seedy if there are compatible pollen sources nearby, and it is almost impossible to exclude honeybee activity during the blooming period. So, although "Moncada" mandarin is a self-incompatible and parthenocarpic cultivar, cross-pollination increases the presence of seeds in the fruits. Gamma irradiation of 3000 "Moncada" budwoods was carried out in the year 2000; the mutation was stabilized by subsequent grafting and around 8400 clones were obtained; their evaluation for seedlessness is still underway. Some clones with few or no seeds in an open pollinated field have been selected for further studies.

In this paper we assess a number of fruit characteristics (number of seeds, pollen viability, fruit size, juice percentage, maturity index) and biofunctional aspects (ascorbic acid, organic acids, flavonoids, carbohydrates, carotenoids and essential oils content) in new clones of "Moncada" mandarin, obtained by bud irradiation. Some authors have reported that irradiation not only affects seed formation in the fruit, but also lowers acidity and increases lycopene carotenoid [20] or favours early ripening [21], while other have reported no changes in seedless cultivars of grapefruits, mandarins and oranges obtained by $\gamma$-irradiation of buds [22]. In our case, some of the clones obtained showed clear differences in certain fruit quality traits.

\section{Materials and Methods}

\subsection{Instruments}

Polytrom PT3100 homogenizer (Kinematica AG, Switzerland) and an Eppendorf 5810R centrifuge (Eppendorf Iberica, Madrid, Spain) were used for sample treatment. Analysis was made using an Alliance liquid chromatographic system (Waters, Barcelona, Spain) equipped with a 2695 separation module, coupled to a 2996 photodiode array detector and a ZQ2000 mass detector. A thermostat column oven, a reverse-phase column $\mathrm{C}_{18}$ Tracer Excel $5 \mu \mathrm{m} 120$ OSDB $(250 \mathrm{~mm} \times 4.6 \mathrm{~mm})$ (Teknokroma, Barcelona, Spain), a reverse-phase column $\mathrm{C}_{30}$ YMC S-5 $\mu \mathrm{m}(250 \mathrm{~mm} \times 4.6 \mathrm{~mm})$, a guard column $\mathrm{YMC}_{30} \mathrm{~S}-5 \mu \mathrm{m}(10 \mathrm{~mm} \times 4.0 \mathrm{~mm})$ (YMC Europe $\mathrm{GmbH}$, Germany), a ICSep ICE-COREGEL 87H3 column (Transgenomic), a ICSep ICE-COREGEL 87H guard kit, and an automatic injector were used for chromatographic separation. Empower 2 software was used for data acquisition. Sample temperature was $5^{\circ} \mathrm{C}$, column temperature was $25^{\circ} \mathrm{C}$ or $35^{\circ} \mathrm{C}$, and the UV-Vis spectra were recorded from 280 to $400 \mathrm{~nm}$. An HPLC system equipped with a Waters 515 HPLC pump, a Waters 2414 refractive index detector and a $20 \mu \mathrm{L}$ loop Rheodyne injector were used for sugar analysis. Empower 2 software (Waters, Spain) was used for data processing. Analysis of essential oils was carried out with a Tracer Ultra (Thermo Scientific, Spain) gasses chromatographic system equipped with a PolarisQ mass detector, Tri Plus autosampler and a Thermo TR-5 ms SQC $(30 \mathrm{~m} \times 0.25 \mathrm{~mm}$ i.d. $\times 0.25 \mu \mathrm{m})$ column of $5 \%$ phenyl polysilphenylene-siloxane. Xcalibur software was used for data acquisition, and the NIST library was employed.

\subsection{Plant Material and Sampling}

Gamma irradiation of 3000 budwoods of "Moncada" mandarin was carried out in the year 2000, using a cobalt $\left({ }^{60} \mathrm{Co}\right)$ source at $(50 \pm 10) \%$ Gys. Budwoods were then grafted onto one-year "Carrizo" citrange $(C$. sinensis $(\mathrm{L})$. Osb. $\times$ Poncirus trifoliata (L.) Raf.) rootstock, held at the 
IVIA, located in Moncada (Valencia, Spain). The following year, around 10,000 buds were selected from the obtained shoots (first generation) and grafted onto "Carrizo" citrange rootstock, placing two buds per tree, at different heights and orientation, in order to have two sources of irradiated material (second generation). These new plants were planted in containers $(3.5 \mathrm{~L})$ in the greenhouse until the spring of 2003, after which they were moved to an experimental field at the IVIA. In total, around of 5000 plants were transplanted, carrying around 8400 irradiated buds from "Moncada" mandarin variety.

"Moncada" mandarin is a self-incompatible parthenocarpic cultivar, and flowers should be pollinated by a compatible cultivar to form seeds. This situation was facilitated by planting intercropped irradiated clones between plants of the cultivar "Fortune" $(C$. clementina Hort. ex Tan. $\times C$. tangerina Hort. ex Tan).

For this study we used one tree of each clone (thirteen clones) and a tree of "Moncada" mandarin as control. The clones were selected based on fruit seed number. All cultivars shared the same environmental, cultural and soil conditions, thus the differences among cultivars were not influenced by climatic factors or crop techniques. Representative samples studied in this paper were harvested on four different dates during two years (12/01/2009, 27/01/ $2009,11 / 01 / 2010$ and 25/01/2010).

\subsection{Seed Numbers and Fruit Quality}

Twenty open flowers, at a growth stage $61-62$ on the Citrus BBCH phenological scale [23] from the different clones and control, were hand-pollinated with fertile pollen of "Fortune" mandarin, previously obtained from recently opened flowers. After full fruit development and maturation, all fruits were counted and harvested on four different dates during two seasons. Weight, height and diameter were measured for each fruit, and seeds per fruit were counted. Juice was obtained from the whole fruits, 15 - 20 fruits per clone and per harvest, using a Zumonat machine (Somatic-AMD, Spain) and analyzed for ${ }^{\circ}$ Brix with a refractometer (Atago Co. Ltd., Japan), acidity by titration with $0.1 \mathrm{~N} \mathrm{NaOH}$ using phenolphthalein as indicator, maturity index and juice percentage.

\subsection{Pollen Germination}

Twenty flowers per clone were harvested and the anthers collected and dried for $24 \mathrm{~h}$ at room temperature in the dark. The pollen grains were hydrated and sown on two glass slide-trays with Brewbaker medium [24]. Ten visual fields were selected from each slide-tray, and the pollen germination percentage recorded.

\subsection{General Procedure for Extraction and Analysis}

\subsubsection{Determination of Total Ascorbic Acid}

One millilitre of filtered juice was mixed with $200 \mu \mathrm{L}$ of 1,4-dithio- $D L$-threitol (DTT, $20 \mathrm{mg} / \mathrm{mL}$ ) and left to react for $2 \mathrm{~h}$ in the dark, then filtered through $0.45 \mu \mathrm{m}$ filter and used for total ascorbic acid determination by HPLCDAD [14]. A reverse-phase $\mathrm{C}_{18}$ column was used with an isocratic mobile phase of methanol: $0.6 \%$ acetic acid (5:95). The total run time was $10 \mathrm{~min}$ at $1 \mathrm{~mL} / \mathrm{min}$, and injection volume was $5 \mu \mathrm{L}$. The retention time of ascorbic acid was $3.8 \mathrm{~min}$, and quantification of ascorbic acid was performed at $245 \mathrm{~nm}$ by external standard calibretion. $L$-Ascorbic acid and DTT were obtained from Sigma (Sigma Co., Barcelona, Spain) and Fluka (Sigma Co., Barcelona, Spain), respectively. All solvents used were of HPLC-grade and ultrapure water (Milli-Q) was used.

\subsubsection{Determination of Organic Acids}

One millilitre of filtered juice was mixed with $1 \mathrm{~mL}$ of $0.1 \% \mathrm{H}_{2} \mathrm{SO}_{4}$ solution, and then the sample was centrifuged at $4^{\circ} \mathrm{C}$ for $5 \mathrm{~min}$ at $8000 \mathrm{x} \mathrm{g}$. The supernatant were filtered through $0.45 \mu \mathrm{m}$ filter and analysed by HPLC$\mathrm{DAD}$, and confirmed by HPLC-MS working in electrospray ion negative conditions. The capillary voltage was $3.0 \mathrm{kV}$, cone voltage $23 \mathrm{~V}$, source temperature $100^{\circ} \mathrm{C}$, desolvation temperature $200^{\circ} \mathrm{C}$ and desolvation gas flow $400 \mathrm{~L} / \mathrm{Hr}$. Full data acquisition was performed scanning 100 to 400 uma in centroid mode. An ICSep ICE-COREGEL $87 \mathrm{H} 3$ column was used with an isocratic mobile phase of $0.1 \% \mathrm{H}_{2} \mathrm{SO}_{4}$ solution. The total run time was 20 $\min$ at $0.6 \mathrm{~mL} / \mathrm{min}$, and injection volume was $5 \mu \mathrm{L}$. Compounds were indentified on the basis of comparing their retention times, UV-Vis spectra and mass spectrum data with corresponding authentic standards. Concentrations were determined using an external calibration curve with citric acid $\left(r_{T}=8.01 \mathrm{~min} ;[\mathrm{M}-\mathrm{H}]^{+} 191 \mathrm{~m} / z\right)$, malic acid $\left(r_{T}=9.41 \mathrm{~min} ;[\mathrm{M}-\mathrm{H}]^{+} 133 \mathrm{~m} / \mathrm{z}\right)$, and succinic acid $\left(r_{T}=11.43 \mathrm{~min} ;[\mathrm{M}-\mathrm{H}]^{+} 117 \mathrm{~m} / \mathrm{z}\right)$. All solvents were of HPLC-grade and ultrapure water (Milli-Q) was used. Standards were obtained from Sigma (Sigma Co., Barcelona, Spain).

\subsubsection{Determination of Flavonoids}

One millilitre of filtered juice was mixed with $1 \mathrm{~mL}$ of $\mathrm{DMSO} / \mathrm{MeOH}(1: 1, \mathrm{v} / \mathrm{v})$, and then the sample was centrifuged at $4^{\circ} \mathrm{C}$ for $5 \mathrm{~min}$ at $8000 \mathrm{x} \mathrm{g}$. The supernatant were filtered through $0.45 \mu \mathrm{m}$ filter and analysed by HPLC-DAD and HPLC-MS using a reverse-phase column $\mathrm{C}_{18}$. A gradient mobile phase consisting in acetonitrile (solvent $\mathrm{A}$ ) and $0.6 \%$ acetic acid (solvent $\mathrm{B}$ ) were used. The flow rate was $1 \mathrm{~mL} / \mathrm{min}$ and injection volume 
was $10 \mu \mathrm{L}$. The conditions were as follow: initial condition of $10 \%$ A for 2 min, reaching $75 \% \mathrm{~A}$ in the following $28 \mathrm{~min}$, and then back to initial condition and held for $5 \mathrm{~min}$ (total run time $35 \mathrm{~min}$ ). HPLC-MS analysis was performed working in electrospray ion positive conditions. The capillary voltage was $3.50 \mathrm{kV}$, cone voltage $20 \mathrm{~V}$, source temperature $100^{\circ} \mathrm{C}$, desolvation temperature $225^{\circ} \mathrm{C}$, cone gas flow $70 \mathrm{~L} / \mathrm{Hr}$ and desolvation gas flow $500 \mathrm{~L} / \mathrm{Hr}$. Full data acquisition was performed scanning 200 to 800 uma in centroid mode. Compounds were indentified on the basis of comparing their retention times, UV-Vis spectra and mass spectrum data with corresponding authentic standards. Concentrations were determined using an external calibration curve with narirutin $\left(r_{T}=14.2 \mathrm{~min} ;[\mathrm{MH}]^{+} 581 \mathrm{~m} / z ; \lambda_{\max }(\mathrm{nm})=227.0 / 283.6 /\right.$ 331.2), diosmin $\left(r_{T}=14.6 \mathrm{~min} ;[\mathrm{MH}]^{+} 609 \mathrm{~m} / z ; \lambda_{\max }(\mathrm{nm})\right.$ = 345.5), hesperidin $\left(r_{T}=14.8 \mathrm{~min} ;[\mathrm{MH}]^{+} 611 \mathrm{~m} / z ; \lambda_{\max }\right.$ $(\mathrm{nm})$, didymin $\left(r_{T}=17.6 \mathrm{~min} ;[\mathrm{MH}]^{+} 595 \mathrm{~m} / z ; \lambda_{\max }(\mathrm{nm})\right.$ $=228.2 / 282.5 / 328.8)$, nobiletin $\left(r_{T}=26.3 \mathrm{~min} ;[\mathrm{MH}]^{+}\right.$ $\left.403 \mathrm{~m} / \mathrm{z} ; \lambda_{\max }(\mathrm{nm})=248.6 / 270.6 / 333.6\right)$ and tangeretin $\left(r_{T}=28.2 \mathrm{~min} ;[\mathrm{MH}]^{+} 373 \mathrm{~m} / z ; \lambda_{\max }(\mathrm{nm})=270.6 / 322.8\right)$ [16,25-27]. Narirutin was purchased from Extrasynthesis (Extrasynthesis, Genay, France), diosmin and hesperidin were obtained from Sigma (Sigma Co., Barcelona, Spain), and didymin, nobiletin and tangeretin were purchased from ChromaDex (Irvine, CA, USA). All solvents used were of HPLC-grade and ultrapure water (Milli-Q) was employed.

\subsubsection{Determination of Carbohydrates}

Two millilitres of juice were centrifuged at $8000 \mathrm{x} \mathrm{g}$, for $5 \mathrm{~min}$ at $4^{\circ} \mathrm{C}$. The samples were filtered through $0.45 \mu \mathrm{m}$ nylon filter and analyzed by HPLC using a column Tracer Carbohydr $250 \mathrm{~mm} \times 4.5 \mathrm{~mm}, 5 \mu \mathrm{m}$ (Teknokroma, Barcelona, Spain) and a mobile phase composed by acetonitrile:water $(75: 25)$ at a flow rate of $1 \mathrm{~mL} \mathrm{~min}^{-1}$. Fructose, glucose and sucrose sugars were indentified comparing their retention time with a standard and quantified using an external calibration curve.

\subsubsection{Determination of Carotenoids}

Twenty millilitres of filtered juice were mixed with 10 $\mathrm{mL}$ of ethyl acetate $(0.05 \% \mathrm{BHT})$ and $0.5 \mathrm{~g}$ of basic magnesium carbonate. The sample was centrifuged at $8000 \mathrm{x} \mathrm{g}$ at $4^{\circ} \mathrm{C}$ for $10 \mathrm{~min}$, the supernatant was collected in a $250 \mathrm{~mL}$ decantation funnel and the pellet was reextracted with $20 \mathrm{~mL}$ of ethyl acetate $(0.05 \% \mathrm{BHT})$ and supernatant transferred to the decantation funnel. The organic phase was washed three times with $\mathrm{NaCl}$-saturated water, collected and dried on a bed of anhydrous sodium sulphate. Ethyl acetate was removed in a vacuum rotary evaporator at $40^{\circ} \mathrm{C}$. Residue was dissolved in 5 $\mathrm{mL}$ of ethyl ether and saponified with $2.5 \mathrm{~mL}$ of $20 \%$
$\mathrm{KOH}$ in methanol overnight in dark. Saponified extract was transferred to a $250 \mathrm{~mL}$ decantation funnel, mixed with $20 \mathrm{~mL}$ of diethyl ether and washed three times with $\mathrm{NaCl}$-saturated water. Diethyl ether was collected, dried with anhydrous sodium sulphate, and evaporated. Dried samples were dissolved in $1 \mathrm{~mL}$ ethyl acetate and analysed by HPLC-DAD using a $\mathrm{C}_{30}$ column. The flow rate was $1 \mathrm{~mL} / \mathrm{min}$ and injection volume was $20 \mu \mathrm{L}$. A ternary mobile phase of water (A): methanol (B): methyltert-butyl ether $(\mathrm{C})$ was used. Initial conditions were $4 \%$ $\mathrm{A}, 86 \% \mathrm{~B}$ and $10 \% \mathrm{C}$ held for $10 \mathrm{~min}$, then changed to $4 \% \mathrm{~A}, 10 \% \mathrm{~B}$ and $90 \% \mathrm{C}$ for the next $40 \mathrm{~min}$, and back to initial conditions and conditioning column for $10 \mathrm{~min}$, total run time $60 \mathrm{~min}[28,29]$. Compounds were indentified on the basis of comparing their retention times and absorption spectrum characteristics. Carotenoids were quantified using calibration curves with $\beta$-cryptoxanthin $\left(r_{T}=27.6 \mathrm{~min} ; \lambda_{\mathrm{I}-\mathrm{III}}(\mathrm{nm})=428 \mathrm{sh} / 452 / 478\right)$ and $\beta$-carotene $\left(r_{T}=32.9 \mathrm{~min} ; \lambda_{\mathrm{I}-\mathrm{III}}(\mathrm{nm})=427 \mathrm{sh} / 454 / 475\right)$, with several concentrations. $\beta$-Cryptoxanthin was obtained from Extrasynthese (Extrasynthesis, Genay, France), and $\beta$-carotene was purchased from Biochemica (Sigma Co., Barcelona, Spain).

\subsubsection{Essential Oils}

A head-space system by direct injection to draw off volatile organic compounds (incubation time of $20 \mathrm{~min}$ at $40^{\circ} \mathrm{C}$ ) was used. Representative samples $(5 \mathrm{~mL})$ of juice were analysed by Gas Chromatography-Mass Spectrometry (GC-MS). The initial column oven temperature was $60^{\circ} \mathrm{C}(5 \mathrm{~min})$ and two ramps were used: column oven temperature was increased by $5^{\circ} \mathrm{C} / \mathrm{min}$ to $230^{\circ} \mathrm{C}$ ( 1 min, ramp-1) and then by $40^{\circ} \mathrm{C} / \mathrm{min}$ to $300^{\circ} \mathrm{C}(10 \mathrm{~min}$, ramp-2). Hellium was used as carrier gas and the injecttion was made in split mode (split radio 50), and the injection volume was $1 \mathrm{~mL}$. Mass detector conditions were as follows: acquisition mass range $30-400 \mathrm{amu}$ in full scan mode in positive polarity, source temperature of $225^{\circ} \mathrm{C}$ and damping gas $(\mathrm{He})$ flow, $0.3 \mathrm{~mL} / \mathrm{min}$. Compounds were indentified on the basis of comparing their retention times and mass spectrum characteristics. Pure standards $\alpha$-pinene $\left(r_{T}=7.11 \mathrm{~min}\right)$, myrcene $\left(r_{T}=8.98\right.$ $\min )$, limonene $\left(r_{T}=10.24 \mathrm{~min}\right)$ and $\beta$-pinene $\left(r_{T}=8.56\right.$ min), were obtained from Sigma, Aldrich or Fluka (Sigma Co., Barcelona, Spain).

\subsection{Data Analysis}

Data were expressed as means. One-way ANOVA analyses were carried out with the Statgraphics Plus package, and the Duncan test method $(\mathrm{P}<0.05)$ was applied to experimental data and to estimate significant differences amongst data. 


\section{Results and Discussion}

\subsection{Fruit Seeds Number and Pollen Germination}

Self-incompatible citrus cultivars grown in solid plantation do not produce seeds, but when other cultivars with compatible pollen are close, cross-pollination occurs and seeds are formed in the fruits. The seed numbers obtained by hand cross-pollination were higher than those obtained in open-pollination. Forced pollination leads to fecundation of almost all ovules in the ovary; therefore, low seed number is indicative of low viability of the seminal rudiments present in the flower. Because seedlessness is such an important attribute of citrus quality, demanded both for fresh consumption and industrial processing, the primary target for irradiation is seedlessness. Irradiation is a valuable tool to obtain seedless cultivars from seedy ones. Mutation also affects pollen viability. Female and male sterility seem to be directly related, so clones with a lower seed number also present lower pollen viability, and the impairing chromosomes during meiosis activated by irradiation are responsible, in some cases, for sterility [19,30-32].

The selection process began in 2004 and ended in 2009. Seed number was determined by cutting the fruit transversely in the field. After full fruit development and maturation, all fruits were counted and harvested, and seeds from each fruit were counted. All clones studied presented a lower and significantly different seed number compared to the control "Moncada" mandarin when hand cross-pollinated with fertile pollen from "Fortune" mandarin. This would clearly indicate radiation affected the fertility of ovules present in the mutant cultivar flowers. The lowest value corresponded to clone 4R02, with an average number of 1.30 seeds per fruit, followed by clones 1R03 and 2L09 (1.75 and 1.80 seeds, respectively), whereas the control "Moncada" mandarin showed an average number of 14.70 seeds. None of the clones had an average seeds number above 3.35 seeds per fruit (Figures 1 and 2). Moreover, all clones showed reduced pollen germination compared to the control "Moncada" mandarin, with significantly different values. Control "Moncada" mandarin gave a pollen germination value of $83.30 \%$, while clones 4R02 and 2L09 presented the lowest pollen germination ( $1.15 \%$ and $0.65 \%$, respectively). All clones had pollen germination values below $12 \%$ (Figure 1).

\subsection{Fruit Quality: Nutritional Quality}

Fruit weight, size, acidity, maturity index and harvest time, as well as chemical and nutritional composition are all important quality traits, consequently different fruit quality features have been evaluated in the irradiated

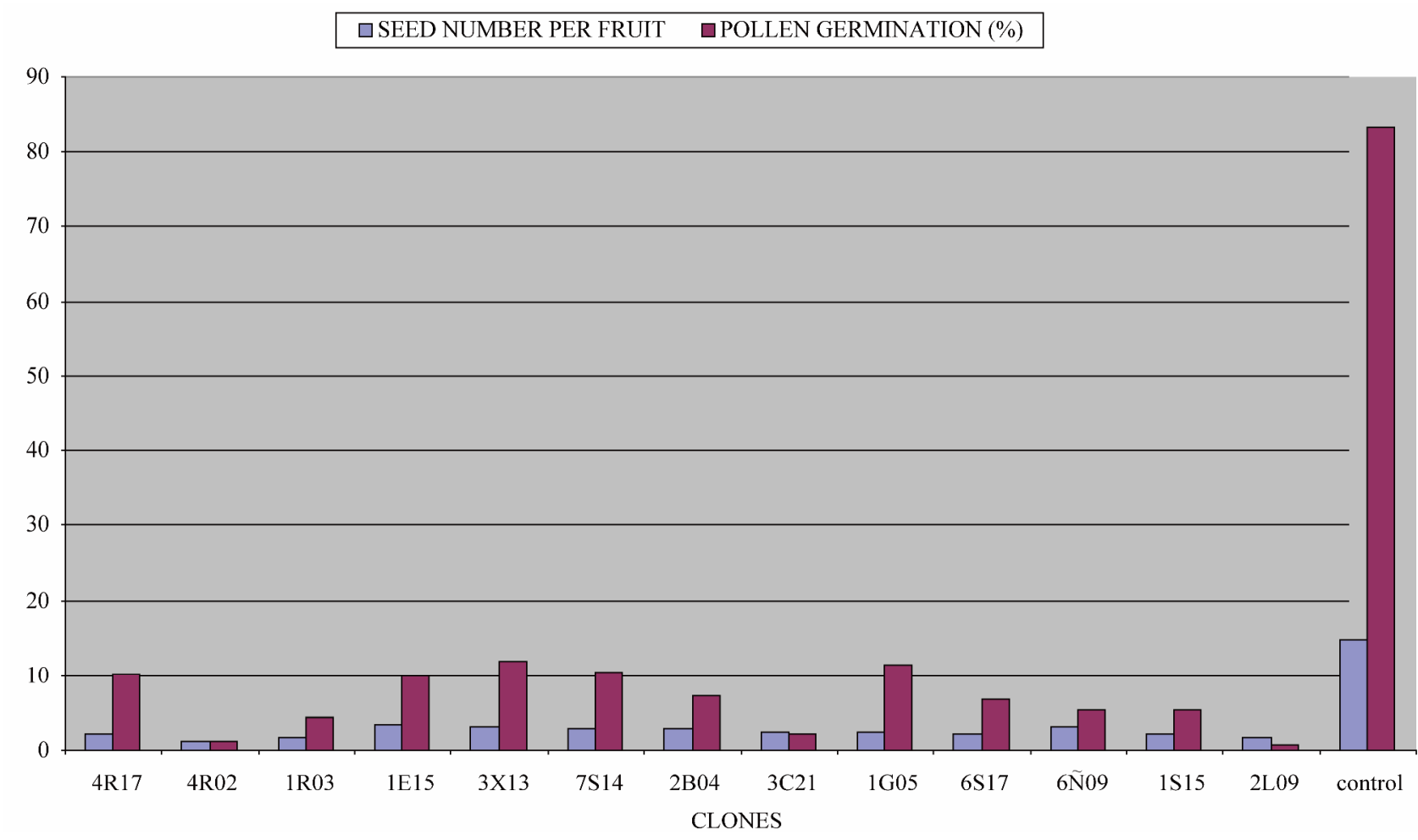

Figure 1. Seed numbers and pollen germination $(\%)$ in several "Moncada" clones, obtained in forced pollination, during 2008/2009 and 2009/2010 seasons. 


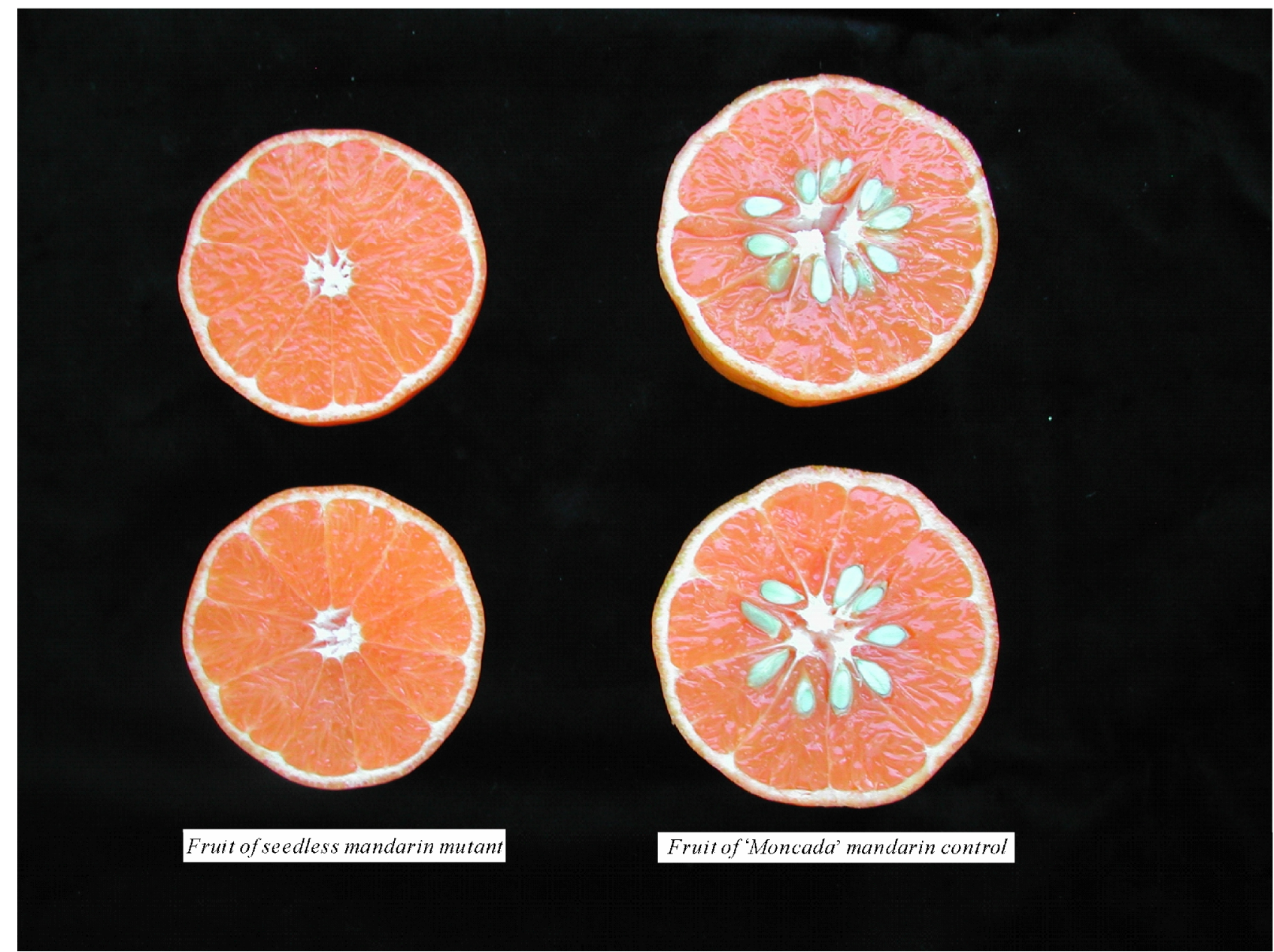

Figure 2. Fruits of seedless mandarin mutant and "Moncada" mandarin control, pollinated with fertile pollen from Fortune.

"Moncada" clones under study (see Table 1). Fruit quality parameters were obtained from representative samples from the whole fruits harvested over two seasons. For the wild-type "Moncada", fruit weight, height and diameter parameters were $129.75 \mathrm{~g}, 49.55 \mathrm{~cm}$ and 67.60 $\mathrm{cm}$, respectively. Weight, height and diameter parameters differed in some of the clones assayed, but only clone 4R02 presented values that were significantly lower than the control $(87.75 \mathrm{~g}, 43.53 \mathrm{~cm}$ and $60.25 \mathrm{~cm}$, respectively). Interestingly, clone 2L09 had an identical fruit height to the control but a significantly lower diameter value, thus emphasizing its rounded shape, it also displayed good rind colour and easy peeling. ${ }^{\circ}$ Brix, acidity and maturity index indicate the maturity status of the fruit. Only clone $1 \mathrm{G} 05$ (with $14.55^{\circ} \mathrm{Brix}$ ) showed a significantly higher ${ }^{\circ}$ Brix value than the control mandarin (with $13.18{ }^{\circ}$ Brix), three clones (4R02, 1G05 and 2L09) had significantly higher acidity values than the control, and two clones (1G05 and 2L09) presented significantly different values compared to the control (see Table 1). It is interesting to note that juice percentage was not influenced by irradiation. The wild-type "Moncada" had a juice percentage of $52.50 \%$, and the clones assayed gave values of between $49.00 \%$ and $54.75 \%$.

\subsubsection{Vitamin $C$ and Organic Acid Content}

Citrus juices are well-known nutrient sources of ascorbic acid (vitamin C) which is an important antioxidant. The content of vitamin $\mathrm{C}$ and other organic acids in fruits and vegetables can be influenced by various factors such as genotypic differences, climatic conditions and cultural practices; furthermore, their nature and concentration largely affect taste characteristics and organoleptic quality [33-35]. The main organic acids of citrus fruits are citric and malic acids. In addition, traces of benzoic, oxalic and succinic acids have also been reported.

Our study revealed few differences in the content of bio-components analyzed in the selected clones. Data of total ascorbic acid are reported in Table $\mathbf{2}$ in milligrams per $100 \mathrm{~mL}$ of juice, and the results are in agreement with our previously reported citrus study of several man- 
Table 1. Fruit quality parameters for the different irradiated "Moncada" clones during 2008/2009 and 2009/2010 seasons"

\begin{tabular}{|c|c|c|c|c|c|c|c|}
\hline Clone & Weight (g) & Diameter $(\mathrm{cm})$ & Height (cm) & ${ }^{\mathbf{o}}$ Brix & Acidity (g/L) & MaturityIndex & $\%$ juice \\
\hline 4R17 & $149.50 \mathrm{a}$ & $70.70 \mathrm{a}$ & $51.56 \mathrm{a}$ & $12.63 \mathrm{~d}$ & $12.58 \mathrm{de}$ & $10.05 \mathrm{abc}$ & $52.50 \mathrm{ab}$ \\
\hline 4R02 & $87.75 \mathrm{e}$ & $60.25 \mathrm{e}$ & $43.53 \mathrm{c}$ & $14.13 \mathrm{abc}$ & $14.35 b c$ & $9.85 \mathrm{bcd}$ & $51.75 \mathrm{ab}$ \\
\hline $1 \mathrm{R03}$ & $130.00 \mathrm{abcd}$ & $66.88 \mathrm{abcd}$ & $50.15 \mathrm{ab}$ & $13.30 \mathrm{bcd}$ & $13.08 \mathrm{cde}$ & $10.20 \mathrm{abc}$ & $54.25 \mathrm{ab}$ \\
\hline $3 \times 13$ & 127.25abcd & 67.78abcd & $50.28 \mathrm{ab}$ & $13.05 \mathrm{~cd}$ & $12.58 \mathrm{de}$ & $10.40 \mathrm{abc}$ & $53.25 \mathrm{ab}$ \\
\hline 7S14 & $120.25 \mathrm{abcd}$ & 67.73abcd & $49.03 \mathrm{ab}$ & $14.15 \mathrm{ab}$ & $13.48 \mathrm{bcd}$ & $10.55 \mathrm{ab}$ & $54.75 \mathrm{a}$ \\
\hline 2B04 & $117.00 \mathrm{bcde}$ & $64.40 \mathrm{bcde}$ & $47.83 \mathrm{abc}$ & $12.88 \mathrm{~d}$ & $11.90 \mathrm{e}$ & $10.88 \mathrm{ab}$ & $50.25 \mathrm{ab}$ \\
\hline $3 \mathrm{C} 21$ & $133.25 \mathrm{abc}$ & $69.48 \mathrm{abc}$ & $49.23 \mathrm{ab}$ & $13.13 \mathrm{bcd}$ & $11.65 \mathrm{e}$ & $11.30 \mathrm{a}$ & $52.75 \mathrm{ab}$ \\
\hline $1 G 05$ & $103.75 \mathrm{cde}$ & $63.35 \mathrm{de}$ & $46.00 \mathrm{bc}$ & $14.55 \mathrm{a}$ & $16.13 a$ & $9.10 \mathrm{~cd}$ & $49.00 \mathrm{~b}$ \\
\hline $6 \mathrm{~S} 17$ & $117.50 \mathrm{bcde}$ & $66.88 \mathrm{abcd}$ & $48.65 \mathrm{ab}$ & $12.98 \mathrm{~d}$ & $12.95 \mathrm{cde}$ & $10.08 \mathrm{abc}$ & $54.50 \mathrm{a}$ \\
\hline 6ก๊̃09 & $143.0 \mathrm{ab}$ & $69.98 \mathrm{ab}$ & $51.05 \mathrm{a}$ & $12.65 \mathrm{~d}$ & $11.73 \mathrm{e}$ & $10.93 \mathrm{ab}$ & $53.75 \mathrm{a}$ \\
\hline $1 \mathrm{~S} 15$ & $148.75 \mathrm{a}$ & $72.38 \mathrm{a}$ & $48.48 \mathrm{abc}$ & $12.35 \mathrm{~d}$ & $12.80 \mathrm{de}$ & $9.68 \mathrm{bcd}$ & $53.00 \mathrm{ab}$ \\
\hline $2 \mathrm{L09}$ & $102.25 \mathrm{de}$ & $59.85 \mathrm{e}$ & $49.30 \mathrm{ab}$ & $12.90 \mathrm{~d}$ & 14.93ab & $8.70 \mathrm{~d}$ & $49.00 \mathrm{~b}$ \\
\hline Control $^{*}$ & $129.75 \mathrm{abcd}$ & $67.60 \mathrm{abcd}$ & $49.55 \mathrm{ab}$ & 13.18bcd & $12.60 \mathrm{de}$ & $10.48 \mathrm{ab}$ & $52.50 \mathrm{ab}$ \\
\hline
\end{tabular}

$\left({ }^{\mathrm{x}}\right)$ : Data are mean $(\mathrm{n}=4)$; Different letters in the same column indicate significant differences $(\mathrm{P}<0.05)$; $(*)$ : "Moncada" mandarin control.

Table 2. Total ascorbic acid (mg/100mL juice) and organic acids (g/L juice) content in several "Moncada" clones during $2008 / 2009$ and $2009 / 2010$ seasons ${ }^{x}$.

\begin{tabular}{|c|c|c|c|c|}
\hline Clone & Ascorbic acid & Citric acid & Malic acid & Succinic acid \\
\hline 4R17 & $22.61 \mathrm{fg}$ & $9.09 \mathrm{j}$ & $10.16 \mathrm{a}$ & $2.88 \mathrm{a}$ \\
\hline $4 \mathrm{R} 02$ & $25.50 \mathrm{bc}$ & $17.49 \mathrm{a}$ & $10.01 \mathrm{ab}$ & $2.73 \mathrm{ab}$ \\
\hline $1 \mathrm{R03}$ & $22.76 \mathrm{gf}$ & $12.03 \mathrm{~d}$ & $9.31 \mathrm{e}$ & $2.46 \mathrm{~cd}$ \\
\hline $1 E 15$ & $23.51 \mathrm{fe}$ & $11.32 \mathrm{e}$ & $8.57 \mathrm{f}$ & $2.57 \mathrm{bcd}$ \\
\hline $3 \times 13$ & $22.09 \mathrm{~g}$ & $9.02 \mathrm{j}$ & $9.83 \mathrm{abc}$ & $2.87 \mathrm{a}$ \\
\hline $7 \mathrm{~S} 14$ & $24.85 \mathrm{dc}$ & $10.79 \mathrm{f}$ & $9.71 \mathrm{bcd}$ & $2.76 \mathrm{ab}$ \\
\hline 2B04 & $24.08 \mathrm{ed}$ & $10.36 \mathrm{~g}$ & $9.35 \mathrm{de}$ & $2.70 \mathrm{abc}$ \\
\hline $3 \mathrm{C} 21$ & 24.17ed & $9.69 \mathrm{i}$ & $7.54 \mathrm{~h}$ & $2.38 \mathrm{~d}$ \\
\hline $1 G 05$ & $26.19 b$ & $12.81 \mathrm{c}$ & $9.60 \mathrm{cde}$ & $2.61 \mathrm{bcd}$ \\
\hline $6 \mathrm{~S} 17$ & $24.55 \mathrm{~d}$ & 9.86hi & $8.90 \mathrm{f}$ & $2.72 \mathrm{abc}$ \\
\hline 6ก்̃9 & $24.46 \mathrm{~d}$ & $8.39 \mathrm{k}$ & $9.29 \mathrm{e}$ & 2.69abc \\
\hline $1 \mathrm{~S} 15$ & 31.01a & $10.13 \mathrm{gh}$ & $10.06 \mathrm{ab}$ & $2.73 \mathrm{ab}$ \\
\hline 2L09 & $21.14 \mathrm{~h}$ & $13.61 b$ & $8.08 \mathrm{~g}$ & $2.54 \mathrm{bcd}$ \\
\hline Control $^{*}$ & $24.44 d$ & $9.01 \mathrm{j}$ & $8.76 \mathrm{f}$ & $2.74 \mathrm{ab}$ \\
\hline
\end{tabular}

$\left({ }^{\mathrm{x}}\right)$ : Data of organic acids are mean $(\mathrm{n}=4)$ during 2009/2010 season, and data of ascorbic acid are mean $(\mathrm{n}=8)$ during 2008/2009 and 2009/2010 seasons; Different letters in the same column indicate significant differences $(\mathrm{P}<0.05) ;(*)$ : "Moncada" mandarin control. 
darin and orange varieties [17]. Ascorbic acid changed significantly in eight clones, three of which (clones 4R02, 1G05 and 1S15) showed a higher ascorbic acid content than "Moncada" mandarin control, which had 24.44 $\mathrm{mg} / 100 \mathrm{~mL}$ of juice. Moreover, three organic acids were separated and identified in all clones: citric, malic and succinic acid. The amounts of each organic acid found are reported in Table 2 in grams per $L$ of juice. As indicated by previous researchers [34], citric acid was the major organic acid found in all clones $(17.49-9.01 \mathrm{~g} / \mathrm{L})$, followed by malic acid (10.16 - 8.08 $\mathrm{g} / \mathrm{L})$, while succinic acid was present in minor quantities. Thus, the content of organic acids followed a similar trend in all the clones studied, although several clones gave citric, malic and succinic acid values that differed significantly from the "Moncada" mandarin control (see Table 2).

\subsubsection{Flavonoid Content}

Flavonoids are widely distributed in fruits and each species is characterized by a particular flavanone glycoside pattern. HPLC with diode array detection and mass spectrometry analytical methods have been used for their identification and characterization [25,36]. Our previous studies on the pulp and rind of orange and mandarin species indicated that the Satsume group present the highest amounts of flavanone glycosides, hesperidin and narirutin compared to the other varieties studied. Contents of other flavonoid compounds showed similarly low tendencies in all citrus cultivars studied $[16,17]$. In the present study, flavonoid hesperidin differed significantly in ten clones, and all of them (except clone 1S15) presented higher hesperidin concentration than the control "Moncada" mandarin. Several clones also had significantly different narirutin, didymin, nobiletin and tangeretin values to the wild-type "Moncada" (see Table 3).

\subsubsection{Carbohydrate Content}

The main portions of carbohydrates in citrus fruits are three simple sugars: fructose, glucose and sucrose, they represent the largest percentage of total soluble solids of citrus juice, and the ratios of fructose:glucose:sucrose are generally about 1:1:2 [34]. This ratio was similar for the irradiated "Moncada" clones under study, and sucrose was present in the largest amounts for all clones (about 79.96 and $116.05 \mathrm{~g} / \mathrm{L}$ ). The wild-type "Moncada" had fructose, glucose and sucrose values of 22.84, 20.32 and $79.96 \mathrm{~g} / \mathrm{L}$, respectively. Sugar composition was similar in the clones and in the control "Moncada" mandarin, although fructose and glucose differed significantly in three clones (fructose in 7S14, 1G05 and 6Ñ09; and glucose in 7S14, 1G05 and 6S17), whereas six clones showed sucrose values which differed significantly from the control (see Table 4). It is interesting to note that clone $6 \mathrm{~S} 17$ showed a significantly higher content of glucose and sucrose compared to the control.

\subsubsection{Carotenoid Content}

The most abundant carotenoids reported in Citrus sp. are $\beta$-carotene, $\beta$-cryptoxanthin, lutein and zeaxanthin, all of them with antioxidant activity [14]. Extracts of citrus fruit peel and pulp are an important and complex source of carotenoids, which are natural pigments, in considerable amounts and in all species. It would be very interesting to establish the relationship between carotenoid accumulation in the fruit, biogenetic routes and genetic diversity in Citrus sp.

Our results are reported in Table 4 in $\mu \mathrm{g}$ per $100 \mathrm{~mL}$ of juice. $\beta$-Cryptoxanthin and $\beta$-carotene were identified on the basis of comparing their retention times and absorption spectrum characteristics with corresponding authentic standards. The content of $\beta$-cryptoxanthin underwent huge changes in numerous clones, ranging from $425.75 \mu \mathrm{g}$ per $100 \mathrm{~mL}$ (clone $1 \mathrm{R} 03$ ) to $266.88 \mu \mathrm{g}$ per 100 $\mathrm{mL}$ (clone 2B04). All clones presented higher $\beta$-carotene concentrations than the wild-type "Moncada", with significantly different values, around $16 \mu \mathrm{g}$ per $100 \mathrm{~mL}$ for clones 4R17, 4R02 and 1R03 (Table 4).

\subsubsection{Essential Oil Content}

Citrus oils are mixtures of volatile components of terpenic hydrocarbons and oxygenated compounds such as aldehyde, alcohol, ketone and ester derivatives. The chemical variability of essential oils and their relationship to genetic and climatic factors is an important topic for research [37]. Merle et al. [38] made an exhaustive study on rind oils obtained from different varieties of citrus. They were able to identify $98 \%$ of the oil content, and found that the principal component in all the essential oils was the monoterpene limonene, ranging from $88 \%$ to $95 \%$, with myrcene being the second compound in most cultivars.

The gas chromatographic profiles and compositions of essential oils are presented in Table 5. For each sample, the qualitative composition was calculated as a relative percentage of peak area, and components were identified, in agreement with reports in the literature, tentatively based on retention times and mass spectrum characteristics also described in the literature [38]. Our data are in agreement with the reports in the literature, with limonene being the main component identified. Thus, limonene, a monoterpene hydrocarbon, was the most abundant compound with an average percentage of $96 \%$. The second compound was myrcene $(1.24 \%-1.07 \%)$, followed by $\alpha$-pinene with a similar relative percentage in the majority of the cultivars $(0.92 \%-0.67 \%)$. Another monoterpene identified in these oils was $\beta$-pinene $(0.01 \%$ $0.05 \%$ ) (see Table 5). In addition, traces of sabinene, linalool, citronellal, $\alpha$-terpineol, carvones and 3-carene 
Table 3. Flavonoids content (mg/100mL juice) in several "Moncada" clones during 2008/2009 and 2009/2010 seasons

\begin{tabular}{|c|c|c|c|c|c|}
\hline Clone & Narirutin & Hesperidin & Didymin & Nobiletin* & Tangeretin* \\
\hline 4R17 & $1.79 \mathrm{~cd}$ & $17.75 b$ & $0.52 \mathrm{de}$ & $0.24 \mathrm{bcd}$ & $0.70 b c$ \\
\hline $4 \mathrm{R} 02$ & $1.87 \mathrm{c}$ & $15.12 \mathrm{f}$ & $0.54 \mathrm{~d}$ & $0.21 \mathrm{de}$ & $0.69 b c$ \\
\hline $1 \mathrm{R03}$ & $1.30 \mathrm{f}$ & $15.26 \mathrm{f}$ & $0.54 \mathrm{~d}$ & $0.27 \mathrm{a}$ & $0.9 \mathrm{a}$ \\
\hline $1 \mathrm{E} 15$ & $1.46 \mathrm{ef}$ & $16.76 \mathrm{~cd}$ & $0.53 \mathrm{de}$ & $0.22 \mathrm{cde}$ & $0.60 \mathrm{~cd}$ \\
\hline $3 \times 13$ & $1.48 \mathrm{def}$ & $14.70 \mathrm{f}$ & $0.49 \mathrm{e}$ & $0.22 \mathrm{~cd}$ & $0.63 \mathrm{~cd}$ \\
\hline $7 \mathrm{~S} 14$ & $1.52 \mathrm{def}$ & $17.21 \mathrm{bc}$ & $0.55 \mathrm{~cd}$ & $0.21 \mathrm{de}$ & $0.65 \mathrm{~cd}$ \\
\hline 2B04 & $1.74 \mathrm{cde}$ & $16.77 \mathrm{~cd}$ & $0.59 \mathrm{c}$ & $0.22 \mathrm{cde}$ & $0.60 \mathrm{~cd}$ \\
\hline $3 \mathrm{C} 21$ & $1.66 \mathrm{cde}$ & $16.04 \mathrm{e}$ & $0.54 \mathrm{~d}$ & $0.19 \mathrm{ef}$ & $0.53 \mathrm{~d}$ \\
\hline $1 G 05$ & $2.94 \mathrm{~b}$ & $19.32 \mathrm{a}$ & $0.64 b$ & $0.26 \mathrm{ab}$ & $0.54 \mathrm{~d}$ \\
\hline $6 S 17 *$ & $1.59 \mathrm{cdef}$ & $15.97 \mathrm{e}$ & $0.54 \mathrm{~d}$ & $0.22 \mathrm{~cd}$ & $0.60 \mathrm{~cd}$ \\
\hline 6்̃̃9 & $1.64 \mathrm{cde}$ & $16.10 \mathrm{e}$ & $0.55 \mathrm{~cd}$ & $0.24 b c$ & $0.69 b c$ \\
\hline $1 S 15$ & 7.0a & $11.33 \mathrm{~g}$ & $1.17 \mathrm{a}$ & $0.19 \mathrm{f}$ & $0.59 \mathrm{~cd}$ \\
\hline 2L09 & $1.48 \mathrm{def}$ & $16.24 \mathrm{de}$ & $0.45 \mathrm{f}$ & $0.22 \mathrm{cde}$ & $0.77 \mathrm{~b}$ \\
\hline Control $^{* *}$ & $1.77 \mathrm{cde}$ & $15.04 \mathrm{f}$ & $0.51 \mathrm{e}$ & $0.21 \mathrm{de}$ & $0.62 \mathrm{~cd}$ \\
\hline
\end{tabular}

$\left({ }^{\mathrm{x}}\right)$ : Data are mean $(\mathrm{n}=8-10)$; Different letters in the same column indicate significant differences $(\mathrm{P}<0.05)$. $(*)$ : Nobiletin and tangeretin only were analyzed during 2009/2010 season $(\mathrm{n}=6)$. (**): "Moncada" mandarin control.

Table 4. Content of carbohydrates ( $\mathrm{g} / \mathrm{L}$ juice) and carotenoids $(\mu \mathrm{g} / 100 \mathrm{~mL}$ juice) in several "Moncada" clones during 2008/2009 and 2009/2010 seasons ${ }^{x}$.

\begin{tabular}{|c|c|c|c|c|c|}
\hline Clone & Fructose & Glucose & Sucrose & $\beta$-Cryptoxanthin & $\beta$-Carotene \\
\hline 4R17 & $22.52 \mathrm{~cd}$ & $19.79 \mathrm{defg}$ & $84.32 \mathrm{cde}$ & $402.00 \mathrm{ab}$ & 16.13a \\
\hline $4 \mathrm{R} 02$ & $23.36 \mathrm{bcd}$ & $21.18 \mathrm{bcde}$ & 93.04bc & 424.50a & $16.00 \mathrm{ab}$ \\
\hline $1 \mathrm{R03}$ & $24.60 \mathrm{bc}$ & $21.89 \mathrm{bcd}$ & $89.86 \mathrm{bcd}$ & $425.75 a$ & 16.13a \\
\hline $1 \mathrm{E} 15$ & $24.69 b c$ & $22.69 \mathrm{abc}$ & $94.27 b$ & $387.36 \mathrm{ab}$ & $14.88 \mathrm{abc}$ \\
\hline $3 \times 13$ & $22.78 \mathrm{~cd}$ & $19.40 \mathrm{efg}$ & $83.63 \mathrm{cde}$ & $383.88 \mathrm{ab}$ & $13.75 \mathrm{abcd}$ \\
\hline 7S14 & $25.75 a b$ & 23.53ab & $99.74 b$ & $383.25 \mathrm{ab}$ & $12.75 \mathrm{cdef}$ \\
\hline 2B04 & $21.18 \mathrm{~d}$ & $18.45 \mathrm{~g}$ & $80.22 \mathrm{e}$ & $266.88 b$ & $11.75 \mathrm{def}$ \\
\hline $3 \mathrm{C} 21$ & $23.33 \mathrm{bcd}$ & $21.43 \mathrm{bcde}$ & $87.04 \mathrm{cde}$ & $327.00 \mathrm{ab}$ & $14.75 \mathrm{abc}$ \\
\hline $1 G 05$ & $27.74 a$ & $25.06 \mathrm{a}$ & $116.05 a$ & $297.38 \mathrm{ab}$ & $10.25 \mathrm{f}$ \\
\hline $6 \mathrm{~S} 17$ & $24.88 b c$ & 22.78ab & $91.73 \mathrm{bcd}$ & 424.13a & $13.25 \mathrm{bcde}$ \\
\hline 6Ñ09 & 25.81ab & $22.74 \mathrm{abc}$ & 88.53 cde & $380.75 \mathrm{ab}$ & $11.50 \mathrm{def}$ \\
\hline $1 S 15$ & $21.17 \mathrm{~d}$ & $18.64 \mathrm{fg}$ & 82.70de & $322.75 \mathrm{ab}$ & $10.63 \mathrm{ef}$ \\
\hline 2L09 & $24.09 \mathrm{bc}$ & $21.07 \mathrm{bcdef}$ & $86.09 \mathrm{cde}$ & $325.63 \mathrm{ab}$ & $11.00 \mathrm{def}$ \\
\hline Control $^{*}$ & $22.84 \mathrm{~cd}$ & 20.32cdefg & $79.96 \mathrm{e}$ & $274.38 \mathrm{~b}$ & $10.25 \mathrm{f}$ \\
\hline
\end{tabular}

$\left({ }^{x}\right)$ : Data of sugar composition are mean $(n=4)$ during 2009/2010 season, and data of carotenoids are mean $(n=2)$ during 2008/2009 season; Different letters in the same column indicate significant differences $(\mathrm{P}<0.05)$; (*): "Moncada" mandarin control. 
Table 5. Component concentration (\%) of essential oils in several "Moncada" clones during 2008/2009 and 2009/2010 seasons ${ }^{\mathrm{x}}$.

\begin{tabular}{|c|c|c|c|c|}
\hline Clone & $\alpha$-Pinene & $\beta$-Pinene & Myrcene & Limonene \\
\hline $4 \mathrm{R} 17$ & $0.76 \mathrm{a}$ & $0.04 \mathrm{a}$ & $1.18 \mathrm{a}$ & $96.87 \mathrm{a}$ \\
\hline 4R02 & $0.70 \mathrm{a}$ & $0.05 \mathrm{a}$ & $1.15 \mathrm{a}$ & $96.94 \mathrm{a}$ \\
\hline 1R03 & $0.91 \mathrm{a}$ & $0.04 \mathrm{ab}$ & $1.22 \mathrm{a}$ & $96.75 \mathrm{ab}$ \\
\hline 1E15 & $0.80 \mathrm{a}$ & $0.04 \mathrm{ab}$ & $1.19 \mathrm{a}$ & $97.04 \mathrm{a}$ \\
\hline $3 \times 13$ & $0.92 \mathrm{a}$ & $0.03 \mathrm{ab}$ & $1.31 \mathrm{a}$ & $96.33 \mathrm{ab}$ \\
\hline $7 \mathrm{~S} 14$ & $0.75 \mathrm{a}$ & $0.04 \mathrm{a}$ & $1.15 \mathrm{a}$ & $96.86 \mathrm{a}$ \\
\hline 2B04 & $0.87 \mathrm{a}$ & $0.03 \mathrm{ab}$ & $1.24 \mathrm{a}$ & $96.78 \mathrm{ab}$ \\
\hline $3 \mathrm{C} 21$ & $0.75 \mathrm{a}$ & $0.04 \mathrm{ab}$ & $1.15 \mathrm{a}$ & $96.72 \mathrm{ab}$ \\
\hline $1 \mathrm{G} 05$ & $0.71 \mathrm{a}$ & $0.05 \mathrm{a}$ & $1.14 \mathrm{a}$ & $96.99 \mathrm{a}$ \\
\hline $6 \mathrm{~S} 17$ & $0.84 \mathrm{a}$ & $0.04 \mathrm{ab}$ & $1.19 \mathrm{a}$ & $96.71 \mathrm{ab}$ \\
\hline 6ก̃09 & $0.81 \mathrm{a}$ & $0.04 \mathrm{ab}$ & $1.12 \mathrm{a}$ & $96.55 \mathrm{ab}$ \\
\hline $1 \mathrm{~S} 15$ & $0.67 \mathrm{a}$ & $0.01 \mathrm{~b}$ & $1.07 \mathrm{a}$ & $95.73 b$ \\
\hline 2L09 & $0.80 \mathrm{a}$ & $0.03 \mathrm{ab}$ & $1.18 \mathrm{a}$ & $96.88 \mathrm{a}$ \\
\hline Control* & $0.73 a$ & $0.04 \mathrm{ab}$ & $1.16 \mathrm{a}$ & $96.89 a$ \\
\hline
\end{tabular}

$\left({ }^{\mathrm{x}}\right)$ : Data are mean \pm standard deviation $(\mathrm{n}=4)$; Different letters in the same column indicate significant differences $(\mathrm{P}<0.05) ;(*)$ : “Moncada" mandarin control.

were identified, tentatively based on the retention times and mass spectrum characteristics as described in the literature (unpublished data).

\section{Conclusions}

In conclusion, budwood irradiation is a suitable technique to improve cultivars, produce seedless cultivars, adjust ripening time or raise the content of health-promoting compounds. In this paper, we characterized 13 clones obtained from irradiated budwood of the seedy "Moncada" mandarin, assessing the quality parameters of the fruit, chemical composition and seed number.

All irradiated clones examined presented lower seed numbers and reduced pollen germination compared to the control. Irradiation affected not only seed formation in the fruit but also most of the clones differed clearly in several aspects related to fruit quality. Many of the clones showed 10 or more different quality traits when compared with the control "Moncada" mandarin, having higher or lower ${ }^{\circ}$ Brix, acidity, size and maturity index, and different biocomponent contents. In order to understand the development of clones under field conditions, and specific production data, the most promising clones have been grafted onto adult plants in various locations in the Mediterranean area. Currently, several clones with improved quality are candidates to replace the control,
"Moncada" mandarin, and the most promising ones require further study to determine their agronomic behaviour.

In view of the above results, two clones (6S17 and 2L09), which demonstrate excellent traits regarding seed formation and fruit quality, including fruit size, internal quality, good rind colour and easy peeling, are in the process of being registered. Regarding nutritional quality, clones 6S17 and 2L09 are not particularly different from "Moncada" mandarin, differing only in sucrose and carotenoid content. Clone 2L09 is smaller in weight and size, rounder in shape, its maturity index is lower than the "Moncada" mandarin control throughout the ripening period, whereas clone $6 \mathrm{~S} 17$ is very similar in size to "Moncada" mandarin. These clones exceed the normal harvesting period without compromising fruit production the following year. These two clones fulfilled the main requirements of our breeding program: low seed number and late maturing, as well as maintaining or improving fruit quality. However, other clones are still the subject of further study.

\section{Acknowledgements}

This work was supported by research project RTA200800052-00-00 from INIA (Ministerio de Educación y Ciencia, Spain), and the financial help of the European 
Community (FEDER and ESF funds) and Consellería de Agricultura, Pesca y Alimentación (Generalitat Valenciana, Spain). Thanks are due to Dr. S. Zaragoza for his critical review of this manustript. We also thank to M. C. González and A. Quiñones for their statistical assistance during the preparation of this manuscript.

\section{REFERENCES}

[1] W. Ye, Y. Qin, Z. Ye, J. A. Teixeria da Silva, L. Zhang, X. Wu, S. Lin and G. Hu, "Seedless Mechanism of a New Mandarin Cultivar 'Wuzishatangju' (Citrus Reticulata Blanco)," Plant Science, Vol. 177, No. 1, 2009, pp. 19-27. doi:10.1016/j.plantsci.2009.03.005

[2] H. Raza, M. Mumtaz-Khan and A. Ali-Khan, "Review. Seedlessness in Citrus," International Journal of Agriculture \& Biology, Vol. 5, No. 3, 2003, pp. 388-391.

[3] M. Yamamoto, R. Matsumoto and Y. Yamada, "Relationship between Sterility and Seedlessness in Citrus," Journal of the Japanese Society for Horticultural Science, Vol. 64, No. 1, 1995, pp. 23-29. doi:10.2503/ijshs.64.23

[4] C. Anderson, "Scion Cultivar Development in Concordia, Argentina," International Citrus Congress, Proceedings of the International Society of Citriculture, Vol. 1, 2000, pp. 39-41.

[5] X. X. Deng, "Citrus Cultivars Released during the Past 10 Years in China," Proceedings of the International Society of Citriculture, Vol. 1, 2000, pp. 37-38.

[6] A. Vardi, "Strategies and Consideration in Mandarin Improvement Programmes," Proceedings of International Society of Citriculture, Vol. 1, 1996, pp. 109-112.

[7] A. Vardi, I. Levin and N. Carmi, "Induction of Seedlessness in Citrus: From Classical Techniques to Emerging Biotechnological Approaches," Journal of the American Society for Horticultural Science, Vol. 133, No. 1, 2008, pp. 117-126.

[8] D. X. Shen, "Fruit Breeding," 1st Edition, Agricultural Press, Beijing, 1997.

[9] H. Kukimura, F. Ikeda, H. Fujita and T. Maeta, "Brief Descriptions of Mutations in Vegetatively Propagated and Tree Crops," Gamma Field Symposium, No. 15, 1976, pp. 79-82.

[10] R. A. Hensz, "Star Ruby, a New Deep-red-fleshed Grapefruit Variety with Distinct Tree Characteristics," Journal of the Rio Grande Valley Horticultural Society, Vol. 25, 1971, pp. 54-58.

[11] O. Gulsen, A. Uzum, H. Pala, E. Canihos and G. Kafa, "Development of Seedless and Mal Secco Tolerant Mutant Lemons through Budwood Irradiation," Scientia Horticulturae, Vol. 112, No. 2, 2007, pp. 184-190. doi:10.1016/j.scienta.2006.12.040

[12] M. A. Anagnostopoulou, P. Kefalas, E. Kokkalou, A. N. Assimopoulou and V. P. Papaeorgiou, "Analysis of Antioxidant Compounds in Sweet Orange Peel by HPLC-diode array Detection-Electrospray Ionization Mass Spectrometry," Biomedical Chromatography, Vol. 19, No. 2,
2005, pp. 138-148. doi:10.1002/bmc.430

[13] A. D. Caro, A. Piga, V. Vacca and M. Agabbio, "Changes of Flavonoids, Vitamin C and Antioxidant Capacity in Minimally Processed Citrus Segments and Juices during Storage," Food Chemistry, Vol. 84, No. 1, 2004, pp. 99-105. doi:10.1016/S0308-8146(03)00180-8

[14] C. Dhuique-Mayer, C. Caris-Veyrat, P. Ollitrault, F. Curck and M. J. Amiot, "Varietal and Interspecific Influence on Micronutrient Contents in Citrus from the Mediterranean Area," Journal of Agricultural and Food Chemistry, Vol. 53, No. 6, 2005, pp. 2140-2145. doi:10.1021/jf0402983

[15] T. Wu, Y. Guan and J. Ye, "Determination of Flavonoids and Ascorbic Acid in Grapefruit Peel and Juice by Capillary Electrophoresis with Electrochemical Detection," Food Chemistry, Vol. 100, No. 4, 2007, pp. 1573-1579. doi:10.1016/j.foodchem.2005.12.042

[16] A. Bermejo, M. J. Llosá and A. Cano, "Analysis of Bioactive Compounds in Seven Citrus Cultivars," Food Science and Technology International, Vol. 17, No. 1, 2011, p. 55. doi:10.1177/1082013210368556

[17] A. Cano, A. Medina and A. Bermejo, "Bioactive Compounds in Different Citrus Varieties. Discrimination among Cultivars," Journal of Food Composition and Analysis, Vol. 21, No. 5, 2008, pp. 377-381. doi:10.1016/j.jfca.2008.03.005

[18] A. Cano, O. Alcaraz, M. Acosta and M. B. Arnao, "Online Antioxidant Activity Determination: Comparison of Hydrophilic and Lipophilic Antioxidant Activity Using the ABTS ${ }^{+}$Assay", Redox Report, Vol. 7, No. 2, 2002, pp. 103-109. doi:10.1179/135100002125000334

[19] S. Zaragoza, J. Pardo, R. Ibañez and A. Medina, "Obtención de Mandarinas Tardías sin Semillas Mediante la Irradiación de Yemas," Levante Agricola, Vol. 374, No. 1, 2005, pp. 44-50.

[20] R. A. Hensz, "Mutation Breeding and the Development of the Star Ruby Grapefruit," Proceedings of the International Society of Citriculture, Vol. 2, 1977, pp. 582-585.

[21] C. J. Hearn, "Development of Seedless Grapefruit Cultivars through Budwood Irradiation," Journal of the American Society for Horticultural Science, Vol. 111, No. 2, 1986. pp. 304-306.

[22] L. J. Froneman, U. J. Breedt, P. J. J. Koelemoer and P. J. J. Van-Rensburg, "Producing Seedless Citrus Cultivars with Gamma Irradiation," Proceedings of the International Society of Citriculture, Vol. 1, No. 5, 1996, pp. 159-163.

[23] M. Agustí, S. Zaragoza, L. Bleiholder, H. Buhr, H. Hack, R. Klose and R. Staub, “Adaptation de L'echelle BBCH à la Description des Estades Phènologiques de Agrumes de Genre Citrus," Fruits, Vol. 52, 1997, pp. 287-295.

[24] J. L. Brewbaker and B. H. Kwack, "The Essential Role of Calcium Ion in Pollen Germination and Pollen Tube Growth," American Journal of Botany, Vol. 50, No. 9, 1963, pp. 859-865. doi:10.2307/2439772

[25] M. L. Mata-Bilbao, C. Andrés-Lacueva, O. Jáuregui and R. M. Lamuela-Raventós, "Determination of Flavonoids 
in a Citrus Fruit Extract by LC-DAD and LC-MS," Food Chemistry, Vol. 101, No. 4, 2007, pp. 1742-1747.

[26] D. Ruiz, J. Egea, M. I. Gil and F. A. Tomás-Barberá, "Characterization and Quantitation of Phenolic Compounds in New Apricot (Prunus armeniaca L.) Varieties," Journal of Agricultural and Food Chemistry, Vol. 53, No. 24, 2005, pp. 9544-9552. doi:10.1021/jf051539p

[27] B. Weber, B. Hartmann, D. Stöckigt, K. Schreiber, M. Roloff, H. J. Bertram and C. O. Schmidt, "Liquid Chromatography/Mass Spectrometry and Liquid Chromatogramphy/Nuclear Magnetic Resonance as Complementary Analytical Techniques for Unambiguous Identification of Polymethoxylated Flavones in Residues from Molecular Distillation of Orange Peel Oils (Citrus Sinensis)," Journal of Agricultural and Food Chemistry, Vol. 54, No. 2, 2006, pp. 274-278. doi:10.1021/jf051606f

[28] C. Cortés, M. J. Esteve, A. Frígola and F. Torregrosa, "Identification and Quantification of Carotenoids Includeing Geometrical Isomers in Fruit and Vegetable Juices by Liquid Chromatography with Ultraviolet-Diode Array Detection," Journal of Agricultural and Food Chemistry, Vol. 52, No. 8, 2004, pp. 2203-2212. doi:10.1021/jf035505y

[29] A. M. Pupin, M. J. Dennis and M. C. F. Toledo, "HPLC Analysis of Carotenoids in Orange Juice", Food Chemistry, Vol. 64, No. 2, 1999, pp. 269-275. doi:10.1016/S0308-8146(98)00095-8

[30] F. G. Gmitter Jr, X. X. Deng and C. J. Hearn, "Cytogenetic Mechanisms Underlying Fertility and Seedlessness in Citrus," Proceedings of the International Society of Citriculture, Vol. 1, 1992. pp. 125-129.

[31] J. Pardo, A. Bermejo, A. Cano and S. Zaragoza, "La Germinación del Polen y la Formación de las Semillas en los Cítricos", Levante Agricola, Vol. 384, No. 1, 2007, pp. 16-20.

[32] J. Pardo, A. Cano, A. Bermejo and S. Zaragoza, "La Temperatura, la Viabilidad del Polen y la Formación de las Semillas en los Cítricos," Levante Agricola, Vol. 399, No. 1, 2010, pp. 20-29.

[33] M. V. Albertini, E. Carcouet, O. Pailly, C. Gambotti, F. Luro and L. Berti, "Changes in Organic Acids and Sugras During Early Stages of Development of Acidic and Acidless Citrus Fruit," Journal of Agricultural and Food Chemistry, Vol. 54, No. 21, 2006, pp. 8335-8339. doi:10.1021/jf061648j

[34] H. Kelebek, S. Selli, A. Canbas and T. Cabaroglu, "HPLC Determination of Organic Acids, Sugars, Phenolic Compositions and Antioxidant Capacity of Orange Juice and Orange Wine Made from a Turkish cv. Kozan," Microchemical Journal, Vol. 91, No. 2, 2009, pp. 187-192. doi:10.1016/j.microc.2008.10.008

[35] S. K. Lee and A. A. Kader, "Preharvest and Postharvest Factors Influencing Vitamin C Content of Horticultural Crops," Postharvest Biology and Technology, Vol. 20, No. 3, 2000, pp. 207-220. doi:10.1016/S0925-5214(00)00133-2

[36] Y. Nogata, K. Sakamoto, H. Shiratsuchi, T. Ishii, M. Yano and H. Ohta, "Flavonoid Composition of Fruit Tissues of Citrus Species," Bioscience, Biotechnology, and Biochemistry, Vol. 70, No. 1, 2006, pp. 178-192. doi:10.1271/bbb.70.178

[37] A. Verzera, A. Trizzi, M. Zappalá, C. Condurso and A. Cotroneo, "Esencial Oil Composition of Citrus Meyerii Y. Tan and C. Medica L. cv. Diamante and Their Lemon Hybrids," Journal of Agricultural and Food Chemistry, Vol. 53, No. 12, 2005, pp. 4890-4894. doi:10.1021/jf047879c

[38] H. Merle, M. Morón, M. A. Blázquez and H. Boira, "Taxonomical Contribution of Essencial Oils in Mandarins Cultivars," Biochemical Systematics and Ecology, Vol. 32, No. 5, 2004, pp. 491-497. $\underline{\text { doi:10.1016/j.bse.2003.09.010 }}$ 